\title{
Produksi Bahan Kering dan Kadar Nutrien Indigofera zollingeriana di Lahan Gambut Berdasarkan Umur Panen Berbeda Setelah Pemangkasan
}

Dry Matter Production and Nutrient Content of Indigofera zollingeriana on Peatland Area Based on Different Harvesting Age after Trimming

\section{A Ali*, R Artika, R Misrianti, Elviriadi, M Poniran}

Corresponding email:

arsyadi.ali@uin-suska.ac.id

Program Studi Peternakan Fakultas Pertanian dan

Peternakan, Universitas Islam Negeri Sultan Syarif Kasim Riau, Jl. H.R. Soebrantas No. 155 Tuah Madani Pekanbaru 28293 Riau, Indonesia

Submitted: $26^{\text {th }}$ April 2021 Accepted : $25^{\text {th }}$ June 2021

\section{ABSTRACT}

This study aimed to determine the increase of dry matter production and Nutrient changes of Indigofera zollingeriana cultivated in Sapric peat soils with harvest age of 2, 3 and 4 months after pruning. Indigofera foliage was obtained from the existing plot of approximately 3 years old that grown in the experimental field of the UARDS Laboratory of the Faculty of Agriculture and Animal Sciences of UIN Suska Riau. The research design of randomized block design (RBD) was apllied consisting of 3 age treatments with 4 group. Each treatment, consisted of indigofera biomass harvested at 2 months old (2M), 3 months old ( $3 \mathrm{M})$ and 4 months old (4M). The results showed that postponing harvest from 2 months to 4 months significantly $(\mathrm{p}<0.05)$ increased dry matter production of $71.97 \mathrm{~g}$ to $437.62 \mathrm{~g}$ and significantly $(\mathrm{p}<0.05)$ decreased crude protein (CP) content from $27.45 \%$ to $21.23 \%$. Meanwhile, crude fibre (CF), extract ether (EE), ash and nitrogen free extract (NFE) contents were not influence by postponing harvest from 2 to 4 months. The respective ranges of CF, EE, ash and NFE content of $I$. zollingeriana were CF: $15.50 \%-16.50 \%$, EE: $2.11 \%-2.85 \%$, ash: 7.55\%-8.31\% and NFE: $46.39 \%-51.15 \%$. It can be concluded that the dry matter production of I. zollingeriana that grown on Sapric peat soils were significantly influenced by harvest age.

Key words: legume, maturity, nutritive value, peatland

\section{ABSTRAK}

Penelitian ini bertujuan untuk mengetahui peningkatan produksi bahan kering (PBK) dan perubahan kadar nutrien Indigofera zollingeriana (indigofera) yang dibudidayakan di lahan gambut tipe saprik pada umur panen 2, 3 dan 4 bulan setelah pemangkasan (re-growth). Indigofera yang digunakan berumur \pm 3 tahun yang tumbuh di kebun percobaan Laboratorium UARDS Fakultas Pertanian dan Peternakan UIN Suska Riau. Rancangan penelitian yang digunakan adalah rancangan acak kelompok (RAK) yang terdiri dari 3 perlakuan dan 4 kelompok. Perlakuan terdiri dari biomasa indigofera yang dipanen pada umur 2 bulan (2B), 3 bulan (3B) dan 4 bulan (4B). Hasil penelitian menunjukkan bahwa peningkatan umur panen dari 2 bulan ke 4 bulan nyata $(p<0,05)$ meningkatkan PBK indigofera per tanaman dari 71,97 g ke 437,62 g dan nyata $(\mathrm{p}<0,05)$ menurunkan kadar protein kasar (PK) dari 27,45\% ke 21,23\%. Peningkatan umur panen dari 2 ke 4 bulan tidak berpengaruh nyata terhadap kadar serat kasar (SK), lemak kasar (LK), abu dan bahan ekstrak tanpa nitrogen (BETN), dengan kisaran masing-masing SK: 15,50\%-16,50\%, LK: 2,11\%-2,85\%, abu: 7,55\%-8,31\% dan BETN: 46,39\%-51,15\%. Dapat disimpulkam bahwa PBK indigofera yang ditanam di lahan gambut bertipe saprik dipengaruhi umur panen. Produksi bahan kering sangat nyata meningkat pada umur panen 4 bulan setelah pemangkasan. Peningkatan umur panen dari 2 ke 4 bulan menurunkan kadar PK tapi tidak menurunkan kadar SK, LK, abu dan BETN.

Kata kunci: gambut, kadar nutrien, leguminosa, umur panen 


\section{PENDAHULUAN}

Produktivitas dan kualitas nutrien hijauan makanan ternak selain dipengaruhi oleh jenis hijauan dan umur pemotongan juga sangat dipengaruhi oleh daya adaptasi hijauan makanan ternak tersebut terhadap kondisi lingkungan seperti iklim, lahan tempat tumbuh dan kesuburan. Indigofera zollingeriana (indigofera) adalah salah satu jenis hijauan makanan ternak dari kelompok leguminosa semak yang toleran terhadap kekeringan (Abdullah 2014), genangan maupun salinitas (Tarigan et al. 2010) dan kondisi tanah masam (Hassen et al. 2007). Salah satu jenis lahan dengan kondisi masam adalah lahan gambut. Lahan gambut dikenal sebagai lahan yang rapuh atau rentan dengan perubahan karakteristik yang tidak menguntungkan (Masganti et al. 2014), sehingga tidak semua jenis tanaman/komoditas dapat berkembang baik di lahan gambut. Pemilihan komoditas adalah salah satu strategi yang efisien untuk mendapatkan produktivitas tanaman yang tinggi di lahan gambut (Masganti et al. 2017). Toleransi I. zollingeriana terhadap kekeringan dan lahan gambut telah dilaporkan oleh beberapa peneliti. Herdiawan (2013) melaporkan bahwa pada taraf cekaman kekeringan berat $I$. zollingeriana masih dapat tumbuh dan berproduksi sekalipun mengalami penurunan. Sementara itu, Ali et al. (2014) melaporkan bahwa I. zollingeriana yang ditanam di lahan gambut dengan umur pemangkasan 120 hari mempunyai produktivitas dan kualitas nutrisi yang jauh lebih tinggi dibandingkan dengan Lucaena leucocephala.

Ketersediaan kualitas hijauan yang tinggi seperti indigofera adalah sangat penting untuk peningkatan produktivitas ternak dan efisiensi pakan (Kumalasari et al. 2017). Umur panen yang tepat, memberikan kualitas nutrien indigofera yang tinggi, karena kualitas nutrisi sangat dipengaruhi oleh komposisi daun muda dan daun tua. Dinamika komposisi antara daun muda dan daun tua terjadi sesuai waktu pemangkasan (Abdullah 2014). Tarigan et al. (2010) melaporkan bahwa kadar protein kasar (PK) indigofera pada interval pemotongan 90 hari relatif rendah $(23,03 \%-23,60 \%)$ dibandingkan interval pemotongan 60 hari (25,50\%-25,81\%). Lebih rendahnya kadar PK dengan penundaan umur panen kemungkinan terkait dengan peningkatan komponen lainnya seperti fraksi serat. Hal ini diperkuat oleh hasil penelitian Tantalo et al. (2019) dimana peningkatan umur pemangkasan dari 40 hari ke 50 hari meningkatkan fraksi serat (neutral detergent fibre/NDF) tanaman indigofera dari 70,93\% menjadi 81,61\%.

Pemanfaatan lahan gambut untuk budidaya indigofera harus memperhatikan tingkat kematangan gambut. Gambut tipe saprik adalah gambut yang paling matang (Masganti et al. 2017). Ali et al. (2014) melaporkan bahwa I. zollingeriana dapat tumbuh dan berproduksi dengan baik di lahan gambut tipe saprik.
Untuk mendapatkan produksi dan kualitas indigofera yang tinggi di lahan gambut maka penentuan umur panen menjadi sangat penting. Penelitian ini bertujuan untuk mengetahui peningkatan produksi bahan kering (PBK) dan perubahan kadar nutrisi I. zollingeriana yang dibudidayakan di lahan gambut tipe saprik pada umur panen 2, 3 dan 4 bulan setelah pemangkasan (regrowth).

\section{METODE}

\section{Materi dan Tempat Penelitian}

Indigofera zollingeriana yang digunakan pada penelitian ini adalah tanaman yang berumur \pm 3 tahun yang tumbuh di kebun percobaan Laboratorium UIN Agriculture Research and Development Station (UARDS) Fakultas Pertanian dan Peternakan UIN Suska Riau. Analisis kadar nutrisi di lakukan di Laboratorium Nutrisi dan Teknologi Pakan Fakultas Pertanian dan Peternakan UIN Suska Riau.

\section{Prosedur Penelitian \\ Plot, jarak tanam dan pemupukan}

Penelitian ini dilaksanakan di tanah gambut bertipe saprik. Ukuran lahan yang digunakan adalah $13,5 \mathrm{~m} \mathrm{x}$ 13,5 $\mathrm{m}$ dan dibagi atas 4 kelompok (ukuran masingmasing kelompok 1,5 m x 13,5 m). Ke 4 kelompok ini membentuk segi empat, dengan 1 kelompok setiap sisinya. Jumlah indigofera pada masing-masing kelompok adalah 11 batang dengan jarak tanam 1,5 m. Pupuk dasar yang digunakan adalah pupuk organik (feses sapi) dengan dosis sebanyak 10 ton ha ${ }^{-1}$ yang diberikan 1 bulan sebelum pemangkasan (triming). Pupuk anorganik (NPK) diberikan 2 minggu setelah pemangkasan dengan dosis $50 \mathrm{~kg}$ berdasarkan Ali et al. (2013).

Pemangkasan, penandaan, pemanenan dan pengambilan sampel

Pemangkasan dilakukan 2 bulan sebelum pengamatan dilakukan. Tanaman dipangkas $\pm 2,5 \mathrm{~cm}$ dari tempat tumbuh percabangan dengan menggunakan gunting tanaman. Hal ini dilakukan untuk mendapatkan pertumbuhan kembali (re-growth) yang seragam. Penandaan dilakukan untuk mengetahui bagian ranting yang dipanen pada umur 2, 3, dan 4 bulan. Penandaan ini dilakukan secara acak sebelum umur panen 2 bulan menggunakan tali rafia dengan 3 warna yang berbeda. Jumlah tanaman pada masing-masing kelompok yang diambil sebagai sampel adalah 9 tanaman. Tanaman yang berbatasan langsung pada masing-masing kelompok tidak digunakan sebagai sampel. Pemanenan dilakukan dengan menggunakan gunting tanaman. Cabang atau ranting yang dipanen berdasarkan umur panen 2, 3, dan 
4 bulan. Ranting yang dipanen dipilih berdasarkan tanda yang sudah diberikan dan dipotong $\pm 2,5 \mathrm{~cm}$ dari pangkal tempat tumbuhnya ranting, dan langsung ditimbang untuk mendapatkan produksi segar. Kemudian diambil sampel sebanyak $500 \mathrm{~g}$ dari masing-masing bagian tanaman yang telah dipanen untuk keperluan analisa kadar nutrien.

\section{Rancangan Penelitian}

Rancangan penelitian yang digunakan adalah rancangan acak kelompok (RAK) berdasarkan Festing (2014) yang terdiri dari 3 perlakuan dan 4 kelompok. Perlakuan berdasarkan umur panen dan pengelompokkan dibuat berdasarkan pencahayaan matahari. Perlakuan terdiri dari:(1) Biomasa indigofera yang dipanen pada umur 2 bulan (2B); (2) Biomasa indigofera yang dipanen pada umur 3 bulan (3B); (3) Biomasa indigofera yang dipanen pada umur 4 bulan (4B). Perlakuan umur panen dilakukan pada setiap individu tanaman yang terdapat pada masing-masing kelompok dan tanaman dipanen sebanyak 3 kali berdasarkan umur panen, sehingga terdapat 9 sampel biomasa indigofera disetiap umur panen (perlakuan) pada setiap kelompok dan kemudian dikomposit (digabungkan) berdasarkan perlakuan pada setiap kelompok. Sebelum dilakukan panen pada umur 2 bulan, jumlah ranting yang tumbuh pada masing-masing tanaman dihitung untuk menentukan jumlah total ranting. Rataan ranting tanaman pada kelompok 1, 2, 3 dan 4 secara berurutan adalah 16,$9 ; 15,0 ; 14,9$ dan 13,7 serta rataan ranting tanaman yang di panen pada umur panen $2 \mathrm{~B}, 3 \mathrm{~B}$ dan $4 \mathrm{~B}$ secara berurutan adalah 16,0;15,0 dan 14,5 .

\section{Peubah}

\section{Produksi bahan kering}

Produksi bahan kering (PBK) per tanaman dihitung berdasarkan produksi segar dikalikan dengan kadar bahan kering (BK) dan kemudian dikonversi ke PBK per hektar berdasarkan perhitungan PBK pertanaman dikalikan dengan jumlah tanaman per hektar berdasarkan jarak tanam. PBK per hektar per tahun dihitung berdasarkan PBK per hektar tanaman dikalikan dengan frekwensi (banyaknya) pemotongan per panen berdasarkan umur pemotongan dalam 1 tahun.

\section{Kadar nutrien}

Sampel segar diambil sebanyak $500 \mathrm{~g}$ dari masingmasing komposit umur panen 2, 3 dan 4 bulan pada setiap kelompok dan kemudian dikeringkan dalam oven yang bersuhu $60 \mathrm{oC}$ selama 48 jam dan selanjutnya digiling untuk mendapatkan ukuran partikel yang seragam (1 mm) yang digunakan dalam menganalisa kadar nutrien. Kadar protein kasar (PK), serat kasar (SK), dan lemak kasar (LK), abu dan bahan ekstrak tanpa $\mathrm{N}$ (BETN) dianalisa menurut prosedur AOAC (2005).
Tabel 1 Produksi bahan kering (PBK) I. zollingeriana (indigofera) pertanaman, per hektar dan per hektar per tahun pada umur panen 2, 3 dan 4 bulan setelah pemangkasan (re-growth)

\begin{tabular}{lccc}
\hline Umur Panen & g pohon $^{-1}$ & ton ha & ton ha $^{-1}$ th $^{-1}$ \\
\hline 2 bulan (2B) & $71,97^{\mathrm{b}}$ & $0,32^{\mathrm{b}}$ & $1,92^{\mathrm{b}}$ \\
3 bulan (3B) & $173,61^{\mathrm{b}}$ & $0,77^{\mathrm{b}}$ & $3,09^{\mathrm{b}}$ \\
4 bulan (4B) & $437,62^{\mathrm{a}}$ & $1,94^{\mathrm{a}}$ & $5,83^{\mathrm{a}}$ \\
\hline
\end{tabular}

Superskrip yang berbeda pada kolom yang sama menunjukkan perbedaan nyata $(\mathrm{p}<0,05)$

\section{Analisis Data}

Data hasil penelitian dianalisis menggunakan analysis of variance (ANOVA) dengan rancangan acak kelompok Bila terdapat perbedaan yang nyata pada pelakuan, dilakukan uji Duncan's Multiple Range Test (DMRT) pada tingkat 5\% untuk menentukan perbedaan antar perlakuan.

\section{HASIL DAN PEMBAHASAN}

\section{Produksi Bahan Kering (PBK)}

Berdasarkan data pada Tabel 1 dapat dilihat bahwa peningkatan umur panen dari 2 bulan ke 4 bulan nyata $(p<0,05)$ meningkatkan PBK indigofera. PBK per tanaman meningkat dari 71,97 g ke 437,62 g. PBK per hektar per sekali panen meningkat dari 0,32 ton ke 1,94 ton dan PBK per hektar per tahun meningkat dari 1,92 ton ke 5,83 ton. Peningkatan PBK terbesar terjadi dari umur panen 3 bulan ke 4 bulan dengan persentase peningkatan masing-masingnya adalah $152,07 \%$ per tanaman, $152,07 \%$ per hektar per sekali panen dan $88,67 \%$ per hektar per tahun. Peningkatan PBK tanaman indigofera dengan penundaan umur panen disebabkan meningkatnya produksi tajuk (Tarigan et al. 2010) yang ditandai dengan bertambahnya jumlah daun dan ranting (Abdullah \& Suharlina 2010) serta adanya proses lignifikasi (pengayuan). Produksi Bahan Kering indigofera hasil penelitian ini adalah lebih rendah dari hasil penelitian Abdullah \& Suharlina (2010) yang melaporkan bahwa PBK (ha panen ${ }^{-1}$ ) indigofera yang dipanen pada umur 38 hari, 68 hari dan 88 hari secara berturut-turut adalah 2,67 ton, 4,10 ton dan 5,41 ton. Namun demikian PBK (ha th ${ }^{-1}$ ) I. zollingeriana hasil penelitian ini lebih tinggi dibandingkan leguminosa jenis lainnya seperti Desmodium sp. (5,48 ton), A. mangium (4,74 ton), F. congesta 4,70 ton) dan Leucaena sp. (3,65 ton) (Herdiawan \& Krisnan 2014). Hal ini menunjukkan bahwa I. zollingeriana adalah salah satu jenis tanaman herba yang mempunyai produksi atau menghasilkan hijauan pakan yang tinggi sebagaimana yang dilaporkan oleh Abdullah (2010). Berdasarkan hasil penelitian ini, bila dihitung per hari maka peningkatan PBK $I$. zollingeriana per tanaman dari umur panen 2 bulan ke 4 bulan adalah sebesar 6,09 g hari-1. $^{\text {. }}$

\section{Kadar Protein Kasar (PK) Indigofera}

Berdasarkan data Tabel 2 dapat dilihat bahwa peningkatan umur panen dari 2 bulan ke 4 bulan nyata $(p<0,05)$ menurunkan kadar PK indigofera. Kondisi ini 
disebabkan oleh perubahan komposisi daun muda dan daun tua. Semakin tua umur panen maka komposisi daun tua semakin tinggi. Abdullah \& Suharlina (2010) melaporkan bahwa peningkatan umur pemangkasan dari 38 hari menjadi 88 hari meningkatkan proporsi daun tua dari $58,4 \%$ menjadi $75,3 \%$ dan menurunkan proporsi daun muda dari 41,6\% menjadi 24,7\%. Penurunan proporsi daun muda menyebabkan penurunan kadar PK indigofera, karena unsur nitrogen yang merupakan penyusun protein banyak tersimpan pada pucuk dan daun muda (Laka \& Wangge 2018). Nitrogen dibutuhkan oleh tanaman terutama untuk sintesis klorofil, maka konsentrasinya akan mengalami penurunan sesuai dengan lamanya daun berfotosintesis (semakin tua umur daun) (Irwan 2020). Penurunan kadar PK indigofera (leguminosa) dan rumput seiring semakin tuanya umur panen, telah dilaporkan oleh beberapa peneliti. Setiyaningrum et al. (2018) melaporkan bahwa peningkatan umur panen indigofera dari 45 hari ke 90 hari menurunkan kadar PK dari $26,22 \%$ menjadi $21,54 \%$. Sementara itu,Vinyard et al. (2018) mendapatkan bahwa peningkatan umur panen rumput Eragrostis tef dari fase awal reproduktif (boot stage) ke fase pembungaan lanjut (late heading) menurunkan kadar PK dari 18,7\% menjadi 11,9\%. Kisaran kadar PK indigofera yang ditanam di lahan gambut hasil penelitian ini $(21,23 \%-27,45 \%)$ sebanding dengan kadar PK indigofera yang ditanam pada jenis lahan lainnya yaitu 21,54\%-26,22\% (Setiyaningrum et al. 2018), 21,12\%-25,81\% (Tarigan et al. 2010) dan 23,40\%-27,60\% (Abdullah \& Suharlina 2010).

\section{Kadar Serat Kasar (SK) Indigofera}

Pada Tabel 2 kadar SK indigofera berkisar antara 15,50\%-16,50\%. Hasil ini menujukkan kadar SK indigofera di lahan gambut pada umur pemotongan 2-4 bulan relatif rendah. Perbedaan kadar SK pada masingmasing umur panen sangat kecil. Hal ini diduga karena pada umur 2-4 bulan tanaman indigofera yang tumbuh di lahan gambut masih dalam fase vegetatif dan masih relatif muda. Kondisi ini ditandai masih berimbangnya ranting yang edible pada ke 3 umur panen. Pertumbuhan vegetatif ditandai dengan proses pertambahan volume, jumlah, bentuk dan ukuran organ-organ vegetatif seperti daun, batang dan akar yang dimulai dari terbentuknya daun pada proses perkecambahan hingga awal terbentuknya organ generatif. Relatif banyaknya ranting edible pada umur panen 2-4 bulan hasil penelitian ini menunjukkan bahwa proses lignifikasi lanjut belum terjadi. Proses lignifikasi lanjut biasanya terjadi pada jaringan tanam yang telah tua, yang ditandai oleh kadar serat kasar yang tinggi, ditandai dengan kadar lignin meningkat (Yanuartono et al. 2019) dan ikatan antara lignin dan selulosa maupun hemiselulosa menjadi kuat. Kadar SK indigofera tidak menurun dengan perpanjangan umur panen dari 2 ke 4 bulan hasil penelitian ini, relatif berbeda dengan hasil-hasil penelitian tanaman leguminosa sebelumnya di lahan bukan gambut.
Tabel 2 Kadar nutrien I. zollingeriana (\%) pada umur panen 2, 3 dan 4 bulan setelah pemangkasan (re-growth)

\begin{tabular}{|c|c|c|c|c|c|}
\hline Umur Panen & PK & SK & LK & Abu & BETN \\
\hline & & & $\%$ & & -- \\
\hline 2 bulan (2B) & $27,45^{a}$ & 16,50 & 2,11 & 7,55 & 46,39 \\
\hline 3 bulan (3B) & $23,76^{\mathrm{ab}}$ & 15,50 & 2,57 & 7,94 & 50,23 \\
\hline 4 bulan (4B) & $21,23^{b}$ & 16,46 & 2,85 & 8,31 & 51,15 \\
\hline
\end{tabular}

Superskrip yang berbeda pada kolom yang sama menunjukkan perbedaan nyata $(\mathrm{p}<0,05) ; \mathrm{PK}=$ protein kasar; $\mathrm{SK}=$ serat kasar; LK = lemak kasar; BETN = bahan ekstrak tanpa nitrogen

Hasil penelitian ini sejalan dengan Setiyaningrum et al. (2018) dan Savitri et al. (2012) yang menunjukkan bahwa perpanjangan umur panen dari 45 hari ke 90 nyata meningkatan kadar serat kasar indigofera dari $19,22 \%$ menjadi $21,62 \%$ sedangkan pada gamal umur panen dari 60 hari menjadi 90 hari nyata meningkatkan kadar SK dari 14,46\% menjadi 17,18\%. Kondisi ini juga dapat terjadi karena adanya perbedaan lahan (media) tanam, jenis tanaman dan lingkungan (Ali et al. 2014). Kisaran kadar SK indigofera hasil penelitian yang relatif rendah, yaitu 15,50\%-16,50\% (dibawah 18\%), sangat memungkinkan digunakan sebagai sumber bahan pakan ternak non ruminansia (Abdullah \& Suharlina 2010) seperti ternak unggas.

\section{Kadar Lemak Kasar (LK) Indigofera}

Pada Tabel 2 dapat dilihat bahwa peningkatan umur panen dari 2 bulan ke 4 bulan tidak nyata mempengaruhi kadar LK indigofera. Kadar LK indigofera pada umur panen 2 bulan, 3 bulan dan 4 bulan di lahan gambut berkisar antara 2,11\% $-2,85 \%$. Hasil ini setara dengan kadar LK rumput gajah, hasil penelitian Astuti (2011) yang melaporkan bahwa LK rumput gajah yang dipanen pada umur pemotongan 40 hari - 60 hari berkisar antara 1,54\% - 3,72\%. Namun jauh lebih rendah dibandingkan kadar LK alfalfa hasil penelitian Hermanto et al. (2017) yang memberikan dolomit berbeda yaitu sebesar $8,79 \%$ - 10,41\%. Perbedaan hasil ini mengindikasikan bahwa kadar LK hijauan sangat dipengaruhi oleh jenis, umur panen dan perlakuan yang diberikan. Kadar LK indigofera tidak meningkat dengan penundaan umur panen dari 2 bulan ke 4 bulan relatif berbeda dengan hasil penelitian yang diperoleh oleh Astuti (2011) dan Hermanto et al. (2017), yang melaporkan bahwa peningkatan umur panen nyata meningkatkan kadar LK hijauan. Peningkatan kadar LK ini disebabkan oleh semakin tua umur tanaman semakin banyak cadangan energi dalam bentuk lemak kasar yang ditimbun di daun (Astuti 2011).

\section{Kadar Abu Indigofera}

Kadar abu hijauan menunjukkan kadar mineral yang terdapat dalam hijauan tersebut. Semakin tinggi kadar abu maka kadar mineral yang ada dalam hijauan semakin banyak. Pada Tabel 2 menunjukkan bahwa kisaran kadar abu indigofera yang dipanen pada umur 2 bulan , 3 bulan dan 4 bulan adalah 7,55\% - 8,31\% dan perbedaan umur panen ini tidak berpengaruh terhadap kadar abu indigofera. Hasil ini relatif sama dengan hasil 
penelitian yang dilaporkan beberapa peneliti. Herdiawan et al. (2014) melaporkan bahwa peningkatan umur panen dari 60 hari ( 2 bulan) ke 90 hari ( 3 bulan) tidak memberikan pengaruh yang nyata terhadap kadar abu indigofera dengan kisaran (10,12\% - 10,35\%). Hasil penelitian Sriagtula et al. (2017) mendapatkan bahwa perbedaan umur panen pada fase generatif (flowering, soft dough dan hard dough) tanaman sorghum tidak memberikan pengaruh yang nyata terhadap kadar abu pada bagian batang dan daun, dengan kisaran kadar abu pada bagian batang $5,03 \%-6,07 \%$ dan pada bagian daun $11,05 \%-12,59 \%$. Namun hasil penelitian ini sedikit berbeda dengan hasil yang didapatkan oleh Setiyaningrum et al. (2018) yang melaporkan bahwa kadar abu indigofera nyata meningkat dari 10,80\% (pada umur panen 45 hari) ke 12,84\% (pada umur panen 75 hari). Perbedaan ini mungkin dipengaruhi oleh media tempat tumbuh, iklim dan kondisi air tanah. Zhao et al. (2009) melaporkan bahwa kecukupan air akan menurunkan karbohidrat terlarut dan meningkatkan konsentrasi mineral, sebaliknya pada kondisi kering, kadar karbohidrat terlarut meningkat dan konsentrasi mineral menurun.

\section{Kadar Bahan Ekstrak Tanpa Nitrogen (BETN) Indigofera}

Karbohidrat terdiri dari bagian serat kasar dan (BETN). BETN merupakan fraksi karbohidrat yang kaya akan gula dan pati sehingga mudah dicerna. Dengan demikian BETN dapat menggambarkan kadar karbohidrat mudah dicerna pada hijauan yang digunakan sebagai sumber energi untuk ternak yang mengkonsumsinya. Berdasarkan data Tabel 2 dapat dilihat bahwa peningkatan umur panen dari 2 ke 4 bulan tidak memberikan pengaruh yang nyata terhadap perubahan kadar BETN indigofera. Kondisi ini sangat dipengaruh oleh kadar SK indigofera pada setiap umur panen. Pada penelitian ini nilai kadar SK indigofera pada umur panen 2, 3 dan 4 bulan tidak berbeda nyata . Bila kadar SK relatif sama, maka kadar BETN juga menunjukkan nilai yang relatif sama, karena BETN adalah bagian atau fraksi dari karbohidrat setelah dikurangi dengan fraksi seratnya, sehingga nilai SK berkorelasi negatif dengan nilai BETN. Amrullah et al. (2015) melaporkan bahwa kadar SK yang tinggi pada bahan pakan akan menurunkan kadar BETN. Kadar BETN indigofera berdasarkan tingkatan umur panen hasil penelitian ini sedikit berbeda dengan kadar BETN leguminosa hasil penelitian Akpensuen et al. (2018) melaporkan bahwa kadar BETN Stylosanathes guianensis nyata meningkat dari $33,55 \%$ ke $36,82 \%$ pada umur panen 9 ke 21 minggu setelah tanam. Hal ini menunjukkan bahwa kadar BETN leguminosa dipengaruhi oleh jenis, iklim dan lahan tempat tumbuh. Kisaran kadar BETN (46,39\% - 51,15\%) indigofera yang dipanen pada umur 2 bulan, 3 bulan dan 4 bulan hasil penelitian ini adalah lebih tinggi dari kadar BETN Stylosanathes guianensis hasil penelitian Akpensuen et al. (2018) dan sebanding dengan kadar BETN sorghum hasil penelitian Koten et al. (2014) yaitu berkisar 45,84\%$51,78 \%$ pada umur panen $50-70$ hari.

\section{SIMPULAN}

Produksi bahan kering I. zollingeriana yang ditanam di lahan gambut bertipe saprik sangat dipengaruhi oleh umur panen. Peningkatan produksi bahan kering meningkat pada umur panen 4 bulan setelah pemangkasan. Peningkatan umur panen dari 2 bulan ke 4 bulan menurunkan kadar PK dan tidak mempengaruhi kadar SK, LK, abu dan BETN.

\section{DAFTAR PUSTAKA}

Abdullah L. 2010. Herbage production and quality of shrub indigofera treated by different concentration of foliar fertilizer. Media Peternakan. 33 (3): 169-175. doi: 10.5398/medpet.2010.33.3.169.

Abdullah L. 2014. Prospektif agronomi dan ekofisiologi Indigofera zollingeriana sebagai tanamam penghasil hijauan pakan berkualitas tinggi. Pastura. 3 (2): 79 - 83.

Abdullah L \& Suharlina. 2010. Herbage yield and quality of two vegetative parts of indigofera at different times of first regrowth defoliation. Media Peternakan. 33 (1): 44-49.

Akpensuen TT, Luka JS, Okpanachi U, Ishiaku YM, \& Munza BM. 2018. Effects of stage of growth on dry matter yield and nutrients composition of stylo (Stylosanthes guianensis cv. Cook) in Vom, Plateau State, Nigeria. Nigerian Journal of Animal Science Technology. 1 (2):19-28.

Ali A, Abdullah L, Karti PDMH, Chozin MA, \& Astuti DA. 2013. Production, competition indices, and nutritive values of Setaria splendida, Centrosema pubescens, and Clitoria ternatea in mixed cropping systems in peatland. Media Peternakan 36 (2): 209-215. doi:10.5398/medpet.2013.36.3.209.

Ali A, Abdullah L, Karti PDMH, Chozin MA \& Astuti DA). 2014. Production and nutritive value of Indigofera zollingeriana and Leucaena leucocephala in peatland. Animal Production. 16 (3):156164.

Amrullah FA, Liman, \& Erwanto. 2015. Pengaruh penambahan berbagai jenis sumber karbohidrat pada silase limbah sayuran terhadap kadar lemak kasar, serat kasar, protein kasar dan bahan ekstrak tanpa nitrogen. Jurnal Ilmiah Peternakan Terpadu. 3(4): 221-227.

AOAC. 2005. Official Methods of Analysis. Ed ke 18. Airlington (USA) : AOAC International.

Astuti N. 2011. Pengaruh umur pemotongan terhadap kadar nutrien rumput raja (king grass)). Jurnal Agrisains. 2 (1): 18-28.

Festing MFW. 2014. Randomized block experimental designs can increase the power and reproducibility of laboratory animal experiments. ILAR Journal. 55 (3): 472-476. doi: 10.1093/ilar/ilu045.

Hassen A, Rethman NFG, Van Niekerk, \& Tjelele TJ. 2007. Influence of season/year and species on chemical composition and in vitro digestibility of five indigofera accessions. Animal Feed Science and Technology. 136 (3-4):312-322.

Herdiawan I. 2013. Pertumbuhan tanaman pakan ternak legum pohon Indigofera zollingeriana pada berbagai taraf perlakuan cekaman kekeringan. Jurnal Ilmu Ternal dan Veteriner. 8 (4): 258-264. doi:10.14334/jitv.v18i4.332.

Herdiawan I \& Krisnan R. 2014. Produktivitas dan Pemanfaatan Tanaman Leguminosa Pohon Indigofera zollingeriana pada Lahan Kering. Wartazoa. 24 (2): 75-82. doi: http://dx.doi.org/10.14334/wartazoa.v24i2.1051

Herdiawan I, Abdullah L, \& Sopandi D. 2014. Status nutrisi hijauan Indigofera zollingeriana pada berbagai taraf perlakuan stres kekeringan dan interval pemangkasan. Jurnal Ilmu Ternak dan Veteriner. 19 (2): 91-103.

Hermanto, Suwignyo B, \& Umami N. 2017. Kualitas kimia dan kadar klorofil tanaman Alfalfa (Medicago sativa L.) dengan lama penyinaran dan dosis dolomit yang berbeda pada tanah regosol. Buletin Peternakan. 41 (1): 54-60. doi:10.21059/buletinpeternak. v41i1.9831. 
Irwan Z. 2020. Kadar zat nutrien daun kelor (Moringa oleifera) berdasarkan metode pengeringan. Jurnal Kesehatan Manarang. 6 (1): $69-77$.

Koten BB, Soetrisno RD, Ngadiyono N, \& Soewignyo B. 2014. Perubahan nilai nutrient tanaman sorgum (Sorghum bicolor (L.) Moench) varietas local rote sebagai hijauan pakan ruminansia pada berbagai umur panen dan dosis pupuk urea. Pastura. 3 (2) : 55-60.

Kumalasari NR, Wicaksono GP, \& Abdullah L. 2017. Plant growth pattern, forage yield, and quality of Indigofera zollingeriana influenced by row spacing. Media Peternakan. 40 (1):14-19. doi: https://doi.org/10.5398/medpet.2017.40.1.14.

Laka M \&Wangge ESA. 2018. Uji kadar protein pada beberapa varietas umbi ubi kayu (Manihot esculenta Crantz) yang dihasilkan di Desa Randotonda, Kecamatan Ende, Kabupaten Ende. AGRICA. 11 (1) : 43-50.

Masganti, Anwar K, \& Susanti MA. 2017. Potensi dan pemanfaatan lahan gambut dangkal untuk pertanian. Jurnal Sumberdaya Lahan. 11 (1): 43-52.

Masganti, Wahyunto, Dariah A, Nurhayati, \& Yusuf R. 2014. Karakteristik dan potensi pemanfaatan lahan gambut terdegradasi di Provinsi Riau. Jurnal Sumberdaya Lahan. 8 (1): 59-66.

Savitri MV, Sudarwati H, \& Hermanto. 2013. Pengaruh umur pemotongan terhadap produktivitas gamal (Gliricidia sepium) Jurnal Ilmu-Ilmu Peternakan. 23 (2): 25-35.

Setiyaningrum E, Kaca IN, \& Suwitari NKE. 2018. Pengaruh umur pemotongan terhadap produksi dan kualitas nutrisi tanaman indigofera (Indigofera Sp). Gema Agro. 23 (1): 59-62. doi:10.22225/ga.23.1.660.59-62.

Sriagtula R, Karti PDM.H, Abdullah L, Supriyanto, \& Astuti DA. 2017. Nutrient changes and in vitro digestibility in generative stage of M10-BMR sorghum mutant lines. Media Peternakan. 40 (2):111117.

Tantalo S, Liman, \& Fathul F. 2019. Efek umur pemangkasan indigofera (Indigofera zollingeriana ) pada musim kemarau terhadap kadar neutral detergent fibre dan acid detergent fibre. Jurnal Ilmiah Peternakan Terpadu. 7(2): 241-246.

Tarigan A, Abdullah L, Ginting SP, \& Permana IG. 2010. Produksi dan komposisi nutrisi serta kecernaan in-vitro Indigofera $s p$. pada interval dan tinggi pemotongan berbeda. Jurnal Ilmu Ternak dan Veteriner. 15 (2): 188-195.

Vinyard JR, Hall JB, Sprinkle JE, \& Chibisa GE. 2018. Effects of maturity at harvest on the nutritive value and ruminal digestion of Eragrostis tef (cv. Moxie) when fed to beef cattle. Journal of Animal Science. 96 (8) :3420-3432. doi:10.1093/jas/sky202.

Yanuartono, Purnamaningsih H, Indarjulianto S, Nururrozi A, Raharjo S \& Haribowo N. 2019. Perlakuan biologis dengan memanfaatkan fungi untuk meningkatkan kualitas pakan ternak asal hasil samping pertanian. Jurnal Peternakan Sriwijaya. 8 (2): 18-34.

Zhao CX, He MR, Wang ZL, Wang YF, Lin Q. 2009. Effects of different water availability at post-anthesis stage on grain nutrition and quality in strong-gluten winter wheat. Comptes Rendus Biologies. 332 (8): 759-764. doi: 10.1016/j.crvi.2009.03.003 